\title{
Analysis on the Image of Bath Woman in Canterbury Tales
}

\section{Chen Yongping}

Hainan College of Vocation and Technique, Haikou city, Hainan Province, China 570216

\begin{abstract}
Keywords: Canterbury Tales; The image of Bath woman; Jeffrey Chaucer; Medieval times
\end{abstract}
\begin{abstract}
Canterbury Tales is a collection of poetical style short stories by Jeffrey Chaucer, which has a very important influence on British society at that time. The image of Bath woman in Canterbury Tales is discussed in this paper to lay a deep foundation for later generations to understand this work.

Geoffrey Chaucer was the greatest poet and astronomer in English history, known as the "father of English literature". "Canterbury Tales" is his most famous masterpiece. In this poetical literary work, the main creative background is one real day of Jeffrey Chaucer, in which the author respectively set up housewives, doctors, lawyers, pilgrims and other images. These characters are extremely distinctive, especially women image in Bath city, which is vividly described by the author, and Chaucer also revealed the reality and darkness in medieval period of British society through the description of Bath women's image, words and deeds [1]. Based on this, the article takes the whole story of Canterbury Tales as the premise to analyze the image of Bath woman.
\end{abstract}

\section{The artistic perspective of Canterbury Tales}

\section{A. Feminist perspective}

As early as the 1970s, Eileen Dellmund and others rewrote this literary work and began to criticize it from feminist point of view. After that, there were a lot of people who published a number of insights taking female criticism as the main point of view. Chaucer's critiques can be divided into two different factions, namely Carolyn-based "Criticism of husband power system from feminist perspective" and Elaine-based "Female character image has not yet divorced from the era".

B. Critical perspective of Bakhtin's Polyphonic Poetics

"Canterbury Tales" is described in Bakhtin's polyphonic poetics, which was formed mainly at the end of the 20th century, such as "Chaucer's Narrator" by David Lawton et al. [2]. In 1989, the article "Chaucer, Bakhtin and Glor Zelda" was published in "Model", which is a very outstanding representative work in this critical perspective.

\section{Domestic literature perspective}

Chaucer's literary works have been paid much attention by scholars in our country. As early as the 1930s, there were translators who translated the works of Chaucer so that more people could pay attention to his literary works. In 1995, Shiming Han published "Father of English literature Jeffrey Chaucer". This book introduced Chaucer's life and then the political and cultural situation of the society, focusing on Chaucer's life story at the time when he was creating "Canterbury Tales" and other literary works.

Chaucer's literary achievement has a pivotal position in the literary world, and the research of Chaucer's literary works in China is mainly embodied in the following points: artistic features and literary themes. In the aspect of artistic characteristics, Canterbury Tales uses an open frame structure, combined with the use of humorous and satirical art techniques, making it become the focus of our scholars. In literary subject, Chinese scholars are always in progress in the study of Chaucer's poetry, especially "Canterbury Tales", which contains many topics. Scholars take religion and female as the two theme focuses of the study. 


\section{The image of Bath woman created in "Canterbury Tales"}

"Canterbury Tales" includes 24 stories, and the preface has a general order, which mainly describes pilgrimage background and the figures coming in context are introduced. For the image of Bath woman, Chaucer described as follows: "Sunday wearing kerchief is more than ten pounds after weighing," "The color of the socks worn is bright red," "Her face is in proud state, while the skin is extremely clean, rosy". Later, the author also used these words to describe his emotional life: "She has quite a life. She had married five men in front of church door, and when young, she had contacts with countless people" "She had her life and she knows how to cure acacia disease".

It is not difficult to see that these words are very ironic. In Chaucer's stories, the description of different characters has its established order, but because of identity issues and social status impact at the time, Chaucer used different figure description ways in "Canterbury Tales" [3]. For this phenomenon, Freud in the theory of psychoanalysis had pointed out that a person's language and behavior are the embodiment of their inner consciousness, that is, a person's words and actions, etc. can reflect the person's psychological thoughts and image. In the main story of the Canterbury Tales, the hero in the story of Bath woman is a young samurai in the palace of Arthur. Before the story begins, Bath woman prepares a long opening speech, which introduces to the "blessed blessing" of the land of Solomon described below. Then she makes a large section of the inevitable link discussion between marriage and chastity, which all reflect her high awareness of female status, such as "I want my husband to be my servant and debt households" "As long as I live one day, his body is still under my control", etc. It can be seen from this opening, Bath woman's goal in life is in fact the control of their husbands, and the idea was very rare in British literature at the time. Because in Chaucer's creation of this passage, the Bath woman used the words in "Old Testament" in a one-sided way, so it was subjected to the irony of forgiving sinful monks who said that Bath woman was a "great" missionary.

For all the stories in Canterbury Tales, the story of Bath woman is not very colorful, but the story has given her distinctive personalities, such as the story which respects the status of women. After the samurai committed a capital offense, his wife and other ladies rescued him, thus, in the story, women's power and status have even gone beyond the "law" [4]. In addition, in the time when the samurai is locked up, his thinking also shows the women concepts. The warrior thinks an old woman helped him, so he thinks of marrying her in the future. When the warriors is pardoned, despite the warrior is extremely reluctant on the wedding night, when he kisses the old woman, the old woman becomes a young girl. This story is also in line with the wishes of the Bath woman, that is, a woman's wish is to control her husband, wanting to be the dominator of the relationship. This can also be seen in the five stories of Bath woman. Thus, Chaucer's woman is a woman with strong feminism, who wants to control her husband, wealthy life, and is not subject to the concept of the times and the concept of marriage.

\section{The content embodied in Bath woman image in "Canterbury Tales"}

\section{A. Human spirit}

At that time, the United Kingdom is still in feudal society, when the female status was still lower than that of men, especially in British medieval stage, when women grew almost in the "second sex" social environment. But "Canterbury Tales", which was a medieval literature, describes such a rebellious image of Bath woman. Poet Jeffrey Chaucer described the characteristics of Bath woman through her own delicate brush strokes, which is also the most distinctive figure in the literary work. Through the cognition of Bath woman image, it is possible to understand that she has rebellious thoughts for social feudalism, the esteem of female status and traditional female chastity. At the same time, the Bath woman opposes the concept of male superiority and oppression of husband over wife, and she clearly put forward her own understanding of marriage, that is, marriage should not be bound by the social environment, and the wife's power should be above her husband. However, the concept of women's rights advocated was unacceptable in the Middle Ages, and under the oppression of religion, people's ideas were greatly 
restricted. In such a social environment, Bath woman dared to propose her own concept and express her dissatisfaction towards the feudal system and the feudal society. This is the embodiment of the liberation of women's ideas, which not only highlights Chaucer advocated realist creative ideas, but also reflects the darkness in the middle Ages.

\section{B. Chaucer's view of the times}

Chaucer's experience as well as his own keen observation laid a foundation for his understanding of society and people. In addition, Chaucer's rich learning experience also increased his sense of humor as a scholar [5]. In England in the 14th century, because it was the Middle Ages, the social system remains at the feudal stage, and various regimes were gradually declining. Although the social class, as an emerging force, showed great vitality, because society had not really developed to the open era, after British's several hundred years of development, coupled with the prevalence of land transactions, the United Kingdom has been on the brink risk. In this economic society inspiration, the public economy got gradual germination, such as the rich Bath woman and handicraftsmen in "Canterbury Tales ". These ordinary citizens have been able to fight against the "land" noble people in the old period, and Chaucer precisely had a correct understanding, so through the portrayal of the Bath woman image, he depicted the characteristics of the society at that time.

The medieval period in Europe is called by people the "dark age", which mainly due to the cultural monopoly of church and monasteries. General people could not use Latin. For Christian doctrine, they could barely understand and master. They lived in the lower class, and the living conditions were much distressed and lacked spiritual level pursuit, and only strived for food and clothing. But the relationship between the upper class, the monasteries and churches was very close, and the guidance of Christianity in marriage and chastity can also be observed. Chaucer, in spite of being in the upper strata of society, had not neglected the development of the new class. Chaucer himself had a very close connection with the lower class. Although the Bath woman did not go too far, there was no extramarital affair, and she followed the provisions of the Catholic Church which do not allow divorces, Chaucer used sharp strokes on his own vulgar. In Bath woman's uninterrupted marriage, she kept married to the elderly and endowed men, and even abused them after marriage, and remarried after their death. However, the autonomy of marriage and independent economic status also led her to master the power in the family. She has the courage to speak out her inner thoughts, dares to make contrary to the social etiquette. The independent family status and financial, and so on also reflect Chaucer's opposition to the status of traditional women and traditional marriage in the Middle Ages, and encourage people to enjoy it in time. This story and character also demonstrate Chaucer's unique view of the times and inclusiveness, which lays a solid foundation in the face of some of the upcoming literary works.

\section{Conclusion}

To sum up, the article analyzes the image of Bath woman in Chaucer's Canterbury Tales, which reflects the author's background and intention at that time. First, the background of the work is medieval England. In order to break through the feudal society, Chaucer revealed the feudal social system through the Bath woman image. Secondly, the author expounded his view of the times which started from Bath woman, and through this literary work, he advocated the equal status of women rights, laying a solid foundation for later literary studies.

\section{References}

[1] Liu Yangfeng. Wandering between a shrew and a fighter----On the image of Bath woman [J]. Journal of Henan Mechanical \& Electrical Engineering, 2010,02: 68-71.

[2] Liu Min. Interpretation of Chaucer's women emancipation from the image of Bath woman. [J]. Journal of Shandong Youth Politics College, 2014,05: 146-149.

[3] Wang Fan. Knight image analysis in "Canterbury Tales" [J] Chongqing University of Science 
and Technology (Social Science Edition), 2015,09: 112-114.

[4] Wu Chaoping. Interpretation of Chaucer's emancipation of women from the binary opposition from the image of Bath woman. [J]. Journal of Inner Mongolia Agricultural University (Social Science Edition), 2009,01: 410-411.

[5] Yang Jie. Chaucer woman's liberation thinking from the Bath woman [J]. Journal of Hunan Agricultural University (Social Science), 2001,01: 61-64. 